\title{
Analisis Kesulitan Mahasiswa tentang Pembelajaran Pecahan pada Kitab Faroid
}

\author{
Netriwati \\ IAIN Raden Intan Lampung: netriwati@gmail.com
}

Submitted : 23-03-2016, Revised : 25-4-2016, Accepted : 16-06-2016

\begin{abstract}
The phenomenon that occurs in students is the difficulty of them in detailing and sorting out the division of inheritance. In Islam everything is set up but its application in daily life has not been done with that should be. After the authors delve deeper into this material is indeed difficult to understand, especiallyin the details of each received by the heirs very closely related to the learning of mathematics in sub-material fractions. Lack of time allocation used in this material, resulting in them not getting examples of varied questions. The method used is qualitative descriptive method. This method tries to describe and interpret what is in accordance with the growing conditions in the ongoing process. Based on the phenomenon that occurred in the field can be concluded that the difficulties experienced by students is to determine the parts that must be accepted by the heirs that have been set in the Qur'an difficult to apply in everyday life, Islam has set clearly in the Qur'an But this has not been done properly. Another difficulty is also experienced in the learning of mathematics is on the equalization pemyebut of fractions obtained by heirs who are too many are entitled to receive inheritance.
\end{abstract}

Keywords: Analysis; Difficulty; Faroid; Fractional;

\begin{abstract}
Abstrak
Fenomena yang terjadi pada mahasiswa adalah sulitnya mereka dalam merinci dan memilahmilah tentang pembagian harta warisan. Didalam Islam semuanya sudah diatur akan tetapi penerapannya dalam kehidupan sehari-hari belum terlaksana dengan yang seharusnya. Setelah penulis mengkaji lebih dalam ternyata materi ini memang sulit dipahami, terutama pada rincian masing-masing yang diterima oleh ahli waris sangat erat sekali kaitannya denga $n$ pembelajaran matematika pada sub materi pecahan. Kurangnya alokasi waktu yang digunakan dalam materi ini, mengakibatkan mereka belum mendapatkan contoh-contoh soal yang bervariasi. Metode yang digunakan adalah metode deskriptif kualitatif. Metode ini berusaha menggambarkan dan menginterpretasi apa yang ada sesuai dengan kondis yang sedang berkembang dalam proses yang sedang berlangsung. Berdasarkan fenomena yang terjadi dilapangan dapat disimpulkan bahwa kesulitan yang dialami oleh mahasiswa adalah pada menentukan bagian-bagian yang harus diterima oleh ahli waris yang telah diatur dalam Al-Quran sulit untuk diaplikasi dalam kehidupan sehari-hari, Islam telah mengatur dengan jelas dalam Al-Quran akan tetapi hal ini belum dilaksanakan dengan semestinya. Kesulitan lain juga dialami pada pembelajaran matematikanya yaitu pada penyamaan pemyebut dari bilangan pecahan yang diperoleh oleh ahli waris yang terlalu banyak yang berhak menerima warisan.
\end{abstract}

Kata Kunci: Analisi; Kesulitan; Faroid; Pecahan. 


\section{PENDAHULUAN}

Belajar merupakan suatu bentuk perubahan mental yang akan dialami seseorang yang ditunjukkan dengan adanya perubahan-perubahan yang bersifat kognitif, efektif dan psikomotor. Gagne" menyatakan "Learning is a change in human disposition or capability, wichpersists over a period of time, and which is simply ascribable to processes of growth" Menurut pendapat tersebut belajar adalah sebuah perubahan dalam watak atau kemampuan yang bertahan dalam jangka waktu lama yang bukan hanya berasal dari proses pertumbuhan (Gagne, 1977).

Berdasarkan pengalaman penulis belajar agama sewaktu SMA kelas 2 dengan bu Nurjani bahwasannya, pada materi Faroid ( pembagian harta pusaka dalam hukum islam) sulit di pahami dan penerapannya dalam kehidupan beragama belum sesuai dengan aturan yang ditetapkan. Kemudian hasil wawancara dengan dosen mata kuliah fiqih, mahasiswa kurang memahami dalam menyelesaikan soal-soal tentang hukum-hukum faroid tersebut terutama pada perincian dan bagian-bagian yang diterima oleh ahli waris. Seiring dengan masalah diatas juga penulis mewawancarai mahasiswa anggkatan 2011, mereka juga mengatakan hal yang senada, dimana mereka juga mengalami kesulitan pada perincian pecahan-pecahan yang diperoleh masing-masing ahli waris yang ada. Mereka juga mengatakan ketentuan dalam pembagiannya juga sulit dipahami karena adanya penghalang dan ashaba, mengingat orangorang terlalu banyak maka kesulitan dalam menentukan siapa-siapa orangnya yang dapat menerima warisan. Permasalahan lain juga terlihat sewaktu pembagian harta warisan di minang kabau sepertinya belum diterapkan, kejadian yang penulis lihat dilapangan bila orang tua sudah meninggal dunia orang yang banyak mendapat harta warisan adalah pihak perempuan atau ada juga sebalikanya. Kondisi lain juga ada yang paling berkuasa juga mendapatkan warisan yang banyak. Namun dalam kondisi ini siapa yang disalahkan pihak yang keluarga yang ditinggalakan mengatur masing-masing tanpa memandang ajaran islam yang sudah ditetapkan (Syah, 2011).

Pada umumnya masyarakat minang melanggar aturan tersebut atau bisa dikatakan sudah tradisi nenek moyang mereka yang turun menurun melakukan hal tersebut. Bila bapak dan ibu sudah meninggal dunia mereka meninggalkan anak laki-laki dan anak perempuan pembagian harta tersebut belum sesuai dengan aturan yang telah diatur dalam Al-Qur'an. Hukum faroid ini telah di atur dalam Al-Qur'an secara komplit dan jelas sekali. Namun pelaksanaannya mudah-mudah sulit. Hal ini juga erat kaitannya dengan sistem kepemilikan (Hak milik) hak dan tanggung jawab dalam keluarga (mulai dari keluarga inti, sampai ke anak cucu, keponakan, dan sebagainya, atau keluarga besar) (Sabiq, 1996).

Materi pembagian warisan ini dapat diintegrasikan dengan pembelajar pecahan, seperti halnya penjumlahkan pecahan berpenyebut tidak sama dapat dilakukan dengan mencari KPK dari masing-masing penyebutnya, setelah penyebutnya sama baru dijumlahkan pembilangnya". Setelah diperoleh pecahan masing-masingnya baru di kalikan dengan harta peninggalan tersebut. Senada dengan hal ini, setelah penulisi mewawancarai mahasiswa beberapa mahasiswa mereka mengatakan bahwa untuk menganalisa bagian-bagian yang diperoleh oleh ahli waris sangat sulit bila penerima warisnya banyak keturunan (Nasution, 2012). 
Berangkat dari fenomena yang terjadi di lapangan, penulis merumuskan permasalahan yang hendak dikaji yaitu: kesulitan apa saja yang dialami oleh mahasiswa dalam perhitungan hokum faroid? Bagaimana hubungan hukum faroid dengan pembelajaran pecahan?.

Analisis (analysis) adalah kemampuan seseorang untuk merinci atau menguraikan suatu bahan atau keadaan menurut bagian-bagian yang lebih kecil dan mampu memahami hubungan di antara bagian-bagian atau faktor-faktor yang satu dengan faktor-faktor lainnya. Kata analisis banyak digunakan dalam berbagai bidang, baik dalam bidang ilmu bahasa, ilmu sosial maupun ilmu alam (sains) dan lain-lain (Kurnia, 2015).

Pembelajaran Matematika pada materi pecahan sangat erat kaitannya dengan perhitungan harta warisan, jika mahasiswa tidak memahami materi pecahan hal ini akan sulit diselesaikan terutama pada perhitungan pecahan berpenyebut tidak sama. Pelaksanaan pembagian warisan tersebut tergolong kepada bilangan pecahan berpenyebut tidak sama (Sudijono, 2013).

Pecahan terbagi 2 bagian, 1) pecahan yang berpenyebut sama, 2) pecahan yang berpenyebut tidak sama. Pada proses ini akan di bahas pecahan yang berpenyebut tidak sama, karena dalam pembagian faroid nanti pecahan antar bagian-bagian yang akan dibagi penyebutnya tidak sama (Syafrilia, 2015). Penjumlahkan pecahan berpenyebut tidak sama dapat dilakukan dengan mencari pecahan senilai. Menurut Mursal "menyatakan "penjumlahan dua pecahan yang berpenyebut tidak sama dengan menggunakan model konkret dan menggunakan luas daerah". Pendapat lain dari Mursal memaparkan "Penjumlahan pecahan berpenyebut tidak sama terlebih dahulu dilakukan dengan menyamakan penyebutnya dengan cara mencari KPK dari masing-masing penyebut tersebut, setelah penyebutnya sama baru dijumlahkan pembilangnya (Dalais, 2007)".

Al-miirats, dalam bahasa Arab adalah bentuk mashdar (infinitif) dari kata waritsa-yaritsuirtsan-miiraatsan. Maknanya menurut bahasa ialah 'berpindahnya sesuatu dari seseorang kepada orang lain', atau dari suatu kaum kepada kaum lain. Pengertian menurut bahasa ini tidaklah terbatas hanya pada hal-hal yang berkaitan dengan harta, tetapi mencakup harta benda dan non harta benda. Ayat-ayat Al-Qur'an banyak menegaskan hal ini, Di antaranya Allah berfirman (an-Naml: 16) yang artinya: "Hai manusia, kami Telah diberi pengertian tentang suara burung dan kami diberi segala sesuatu. Sesungguhnya (semua) Ini benar-benar suatu kurnia yang nyata". Maksudnya dari ayat diatas adalah nabi Sulaiman menggantikan kenabian dan kerajaan nabi Daud a.s. serta mewarisi ilmu pengetahuannya dan Kitab Zabur yang diturunkan kepadanya. Ayat lain juga mengatakan dalam (al-Qashash: 58), sebagai pewarisnya, yang artinya "Dan berapa banyaknya (penduduk) negeri yang telah kami binasakan, yang sudah bersenang-senang dalam kehidupannya; Maka Itulah tempat kediaman mereka". yang tiada dialami lagi sesudah mereka, kecuali sebahagian kecil. dan kami adalah Pewaris(nya)".

Maksud dari ayat diatas adalah: sesudah mereka hancur tempat itu sudah kosong dan tidak dimakmurkan lagi, hingga kembalilah ia kepada pemiliknya yang hakiki yaitu Allah. Dalam hadits marfu' disebutkan, "Wahai Abu Hurairah, pelajarilah ilmu faroidh (ilmu waris) dan ajarkanlah karena ilmu tersebut adalah separuh ilmu dan saat ini telah dilupakan. IImu warislah yang akan terangkat pertama kali dari umatku." (HR. Ibnu Majah, Ad Daruquthni, Al Hakim, Al Baihaqi. Hadits ini dho'iff). Namun sudah menunjukkan kemuliaan ilmu waris karena Allah Ta'ala telah merinci dalam Al Qur'an mengenai hitungan warisan. Dan Allah yang 
memberikan hukum seadil-adilnya. Beda dengan anggapan sebagian orang yang menganggap hukum Allah itu tidak adil karena suuzhonnya pada Sang Kholiq.

Surat An-nisa' ayat 7 juga menerangkan hak bagian-bagian yang diperoleh oleh masing-masing ahli waris seperti berikut:

Artinya" Bagi orang laki-laki ada hak bagian dari harta peninggalan ibu-bapa dan kerabatnya, dan bagi orang wanita ada hak bagian (pula) dari harta peninggalan ibu-bapa dan kerabatnya, baik sedikit atau banyak menurut bahagian yang telah ditetapkan".

Sejalan dengan surat diatas An-nisa' ayat 12 : yang artinya berbunyi:"Dan bagimu (suami-suami) seperdua dari harta yang ditinggalkan oleh isteri-isterimu, jika mereka tidak mempunyai anak. jika Isteri-isterimu itu mempunyai anak, Maka kamu mendapat seperempat dari harta yang ditinggalkannya sesudah dipenuhi wasiat yang mereka buat atau (dan) seduah dibayar hutangnya. para isteri memperoleh seperempat harta yang kamu tinggalkan jika kamu tidak mempunyai anak. jika kamu mempunyai anak, Maka para isteri memperoleh seperdelapan dari harta yang kamu tinggalkan sesudah dipenuhi wasiat yang kamu buat atau (dan) sesudah dibayar hutang-hutangmu. jika seseorang mati, baik laki-laki maupun perempuan yang tidak meninggalkan ayah dan tidak meninggalkan anak, tetapi mempunyai seorang saudara laki-laki (seibu saja) atau seorang saudara perempuan (seibu saja), Maka bagi masing-masing dari kedua jenis saudara itu seperenam harta. tetapi jika Saudara-saudara seibu itu lebih dari seorang, Maka mereka bersekutu dalam yang sepertiga itu, sesudah dipenuhi wasiat yang dibuat olehnya atau sesudah dibayar hutangnya dengan tidak memberi mudharat (kepada ahli waris). (Allah menetapkan yang demikian itu sebagai) syari'at yang benar-benar dari Allah, dan Allah Maha mengetahui lagi Maha Penyantun.

Surat An-nisa' ayat 176: juga membahas tentang pembagian Pusaka(warisan) yang artmya berbunyi:" Katakanlah "Allah memberi fatwa kepadamu tentang kalalah (yaitu): jika seorang meninggal dunia, dan ia tidak mempunyai anak dan mempunyai saudara perempuan, Maka bagi saudaranya yang perempuan itu seperdua dari harta yang ditinggalkannya, dan saudaranya yang laki-laki mempusakai (seluruh harta saudara perempuan), jika ia tidak mempunyai anak; tetapi jika saudara sperempuan itu dua orang, Maka bagi keduanya dua pertiga dari harta yang ditinggalkan oleh yang meninggal. dan jika mereka (ahli waris itu terdiri dari) Saudara-saudara laki dan perempuan, Maka bahagian seorang saudara laki-laki sebanyak bahagian dua orang saudara perempuan. Allah menerangkan (hukum ini) kepadamu, supaya kamu tidak sesat dan Allah Maha mengetahui segala sesuatu".

Zawil ashabah, yaitu ahli waris yang dapat menerima ashabah.Di antara ahli waris zawil furudl ada juga yang dapat menjadi ashabah yaitu ayah dan kakek.Menurut bahasa ashabah berarti pembela, penolong, pelindung, adan sebagainya dari kaum sendiri.cAshobah adalah jamak dari 'aashib, seperti halnya thalabah adalah jamak dari thaalib. 'ashabah ini adalah anak turun dan kerabat seorang lelaki dari pihak ayah. Mereka dinamakan 'ashabah karena kuatnya ikatan antara sebagian mereka dengan sebagian yang lain.

Kata 'ashabah ini diambil dari ucapan mereka: 'ashabal qaumu bi fulaan, bila mereka bersekutu dengan si fulan. Maka anak laki-laki adalah satu fihak dari' satu segi dari 'ashabah sedang paman (dari fihak ayah) adalah sisi yang lain. Yang dimaksud dengan 'ashabah disini ialah mereka yang mendapatkan sisa sesudah ashhabul furudh mengambil bagian-bagian yang ditentukan bagi mereka.Apabila tidak ada sisa sedikitpun dari mereka (ashhabul furudh), 
maka mereka ('ashabah) tidak mendapatkan apa-apa, kecuali bila 'ashib itu seorang anak lakilaki maka dia tidak akan mendapatkan bagian, bagaimanapun keadaannnya.

Ashabah yang berhak atas semua peninggalan bila tidak didapatkan seorangpun diantara ashhabul furudh. Ashabah Nasabiyah itu ada tiga golongan:

a. Menurut Sayyid Sabiq, Ashabah bi nafsih, ialah semua orang laki-laki yang nasabnya dengan si mayit tidak diselingi oleh perempuan.

Ashabah binafsihi (orang yang menjadiashabah dengan sendirinya) yakni orang yang mengambil semua harta jika ia sendirian (tidak ada pewaris yang lain) atau berhak mengambil semua harta sisa setelah dibagi zawil furudl dan bisa tidak memperoleh apa-apa, jika harta telah abis terbagi pada zawil furudl.

Yang termasuk Ashabah binafsihi ada empat belas orang, yaitu;

1. anak laki-laki,

2. cucu laki-laki dan seterusnya ke bawah.

3. Ayah.

4. Kakek dan seterusnya ke atas.

5. Saudara laki-laki sekandung.

6. Saudara laki-laki seayah.

7. Anak laki-laki saudara laki-laki sekandung.

8. Anak laki-laki dari saudara laki-laki seayah.

9. Paman (saudara laki-laki dari ayah) sekandung.

10. Paman seayah.

11. Anak laki-laki dari paman sekandung.

12. Anak laki-laki dari paman seayah.

13. Laki-laki yang memerdekakan mayat (budak).

14. Perempuan yang memerdekakan mayat (budak)

Amin Husein Nasution berpendapat bahwa ada empat belas golongan ashabah tersebut ada yang dapat bagian tertentu (zawil furudl) serta menjadi ashabah yaitu ayah dan kakek.

b. 'Ashabah bi ghairih, adalah perempuan yang bagiannya separoh dalam keadaan sendirian, dan dua pertiga bila bersama dengan seorang saudara perempuannya atau lebih. Apabila bersama perempuan atau perempuan-perempuan itu terdapat seorang saudara laki-laki, maka disaat itu mereka semuanya menjadi 'ashabah dengan adanya saudara laki-laki tersebut ('Abdurrahman Ad-Dimasyqi, 2014).

Yang termasuk 'ashabah bi ghairih, ada empat orang, yaitu;

1) Anak perempuan bila bersama-sama dengan anak laki-laki.

2) Cucu perempuan bila bersama-sama denagn cucu laki-laki

3) Saudara perempuan sekandung bila bersama-sama dengan saudara laki-laki sekandung.

4) Saudara perempuan seayah bila bersama-sama dengan saudara laki-laki seayah.

c. Amin Husein Nasution mengatakan 'ashabah ma'a ghairih, ialah setiap perempuan yang memerlukan perempuan lain untuk menjadi 'ashabah. 'ashabah ma'a ghairih, (ashabah bersama orang lain), yakni orang-orang yang menjadi ashabah bersama-sama pewaris lain), yakni orang-orang yang menjadi ashabah bersama-sama pewaris lain, tetapi dzawil furudl biasa.

Yang termasuk ashabah ma'a ghairihi, ada enam orang, yaitu: 
1.seorang atau beberapa saudara perempuan sekandung apabila berasama seorang anak perempuan atau lebih.

2.seorang atau beberapa saudara perempuan sekandung apabila bersama seorang cucu perempuan atau lebih.

3. seorang atau beberapa saudara perempuan seayah apabila seorang anak perempuan atau lebih.

4. seorang atau beberapa saudara perempuan seayah apabila bersama seorang cucu perempuan atau lebih.

5. seorang atau beberapa audara perempuan sekandung apabila bersama seorang anak perempuan dan seorang cucu perempuan.

6. seorang atau beberapa saudara perempuan seayah apabila bersama seorang anak perempuan dan seorang cucu perempuan

d. Ashabah Sababiyah

'Ashib Sababiyah adalah maula (tuan) yang memerdekakan. Bila orang yang memerdekakan tidak ada, maka warisan itu bagi ‘ashabahnya yang lelaki.

Berdasarkan teori di atas dapat di jelaskan bahwa pembelajaran pecahan pada materi faroid dapat mengatasi kesulitan mahasiswa dalam menganalisa rincian atau bagian-bagian yang diperoleh oleh ahli waris yang berhak menerima sesuai dengan aturan yang telah dijelaskan dalam islam. Setelah melaksanakan penelitian ini diharapan mahasiswa tidak mengalami kesulitan lagi dalam merinci masing-masing yang berhak menerima ahli waris.

\section{METODE PENELITIAN}

Metode yang digunakan adalah metode deskriptif kualitatif, penulis menggambarkan hasil penelitian secara deskriptif berdasarkan hasil tes tertulis mahasiswa dalam penyelesaian soal tentang faraid, selain itu penulis juga melakukan wawancara langsung kepada subjek yang diteliti. Metode deskriptif adalah suatu metode yang diupayakan untuk mencandra atau mengamati permasalahan secara sistematis dan akurat mengenai fakta dan sifat objek tertentu (Sugiyono, 2013). Metode ini berusaha menggambarkan dan menginterpretasi apa yang ada atau mengenai kondisi atau hubungan yang ada, pendapat yang sedang berkembang, proses yang sedang berlangsung, akibat atau efek yang sedang terjadi, atau kecenderungan yang tengah berkembang.

\section{HASIL PENELITIAN DAN PEMBAHASAN}

Berdasarkan pelaksanaan dilapangan banyak hal yang dapat dikemukakan dalam penelitian ini antara lain: dari 28 orang mahasiswa yang mengikuti perkulihan fiqih pada umumnya mereka kesulitan dalam mempersentasekan bagian-bagian yang diperoleh oleh ahli waris. Pembagian yang berhak menerima dan ada pula penghalang seseorang mendapatkan warisan tersebut. Seperti yang dikemukakan oleh pendapat beberapa orang mahasisiwa setelah di wawancarai, hasil dari wawancara tersebut adalah: Mahasiswa A, mereka mengatakan tingkat kesulitan yang dialami adalah pada proses mempersentasikan berapa ahli waris yang mendapat bagian dari sisa warisan simayat setelah dibayarkan kewajibannya. dan hutang piutangnya. Kesulitan lain juga dikatakannya jika yang berhak menerima warisan 
tersebut masih hidup semua ini lebih banyak lagi riurncian yang harus dilihat aturannya dalam kajian keislaman. Kesulitan lain juga diungkapkan bahwa, jika simayat meninggalkan harta berupa rumah, tanah, kebun, sawah dan ruko, jika hal ini terjadi kesulitan juga pembagiannya.

Mahasiswa keduan yaitu $B$, mereka mengatakan kesulitan yang dialami pada mahjub sulit memahaminya jika pembagian yang diperoleh $1 / 8,1 / 6,1 / 2,2 / 3$, ini semua bisa berubah jika ahli waris yang berhak menerima ada semua. Kesulitan lain juga mereka katakan harta yang menjadi ashaba sulit untuk dipahami, alokasi waktu untuk mempelajari materi faroid ini juga terlalu sedikit hanya 2 kali pertemuan sedangkan memahami materi ini butuh waktu untuk memahami lebih lanjut dan contoh-contoh soal yang diberikan harus lebih beragam untuk bisa memudahkan memahaminya. Untuk mahasiswa selanjutnya yaitu C, juga mengalami kesulitan yang sama dengan mahasiswa yang sebelumnya yaitu pada pembagian - pembagian dari yang telah ditetapkan dalam surat Anissa ayat 7,11 dan 12, jika bagianbagiannya sudah dirinci untuk menghitung berapa yang diterima ahli waris akan mudah di cari. Mahasiswa D juga mengatakan bahwa perhitungan faroid ini banyak yang diabaikan oleh umat islam, mereka dominan menggunakan budaya-budaya suku sebagai contoh : anak terakhir diberi warisan yang lebih dari pada yang lainnya Pada hal Islam secara tegas telah mengatur bagian-bagian yang diperoleh oleh ahli wris jika seseorangan dari ibu/bapak meninggal dunia. Dia juga mengungkapkan bahwa pengoperasian matematikanya tidak terlalu sulit karena hanya menggunakan perkalian $1 / 2,1 / 6,1 / 8,1 / 3,2 / 3$, kesulitan yang dialaminya hanya pada:

1) Pemahaman konsep tentang berapa bagian yang didapat oleh masing-masing anggota keluarga, apalagi dihadapkan dengan permasalahan yang te rlalu banyak keluarga. Hal ini perlu memahami tentang siapa saja yang orang-orang yang terhalang menerima warisan. 2) Penerapan soal dalam bentuk matematika yang serupa dengan aljabar masih sulit dipahami, mereka menyimpulkan materi ini sulit. Kesulitan yang dialami pada mahasisw $\mathrm{E}$ adalah sebagai berikut: Pada pelaksanaan UAS mata kuliah figih ada 2 buah soal tentang faroid dimana mereka belum paham tentang pembagian-pembagian dari keadaan tersebut, mereka belum mengerti mana yang ashaba dan mana yang terhalang menerima warisan, hal lain juga pengalokasian waktu yang sangat minim sekali membuat mereka belum puas mempelajari hukum faroid ini sedetailnya. Waktu yang tersedia hanya lebih kurang 1,5 jam. Kesimpulan terakhir soal tentang faroid tidak bisa dikerjakan, pada hal mahasiswa ini sewaktu belajar aljabar linear dengan penulis tergolong mahasiswa yang pintar (Abdurrahman, 2003).

Berdasarkan keterangan dari lima mahasiswa tersebut dapat disimpulakann bahwa pada umumnya mereka mengalami kesulitan yang sama diantaranya pada pembagian rincianrincian masing-masing yang diterima oleh ahli waris dan menentukan mana yang berhak menerima, mana yang terhalang dan mana yang sebagai asahba. Kesimpulan juga terdapat pada apabila yang penerima ahli waris hidup semua / banyak ini semua pecahaan yang telah ditetapkan awalnyaa akaana berubah.

Analisis dalam kegiatan belajar mahasiswa, pada umumnya berlangsung baik hanya saja dalam memahami siapa yang wajib menerima, siapa yang terhalang menerima warisan karena ada sesuatu hal mahasiswa sangat suasah memahaminya. Kemampuan mahasiswa dalam menyerap apa yang dipelajari masih terlihat kurang sekali. Akan tetapi bila rincian atau peraentasi dari bagian-bagian yang diteria oleh ahli waris mereka sudah bias menyelesaikan soal-soal yang diberikan. Secara keseluruhan dapat disimpulkan bahwa dalam merinci dan 
memilah-milah bagian-bagian yang diterima oleh ahli waris mahasiswa merasa kesulitan untuk pengaplikasiannya. Untuk perhitungan matematikanya jika rincian atau bagian-bagian yang diperoleh sudah dikeketahui mereka tidak kesulitan untuk menghitungnya.

\section{SIMPULAN DAN SARAN}

Berdasarkan hasil tes akhir setelah di analisis dari 5 soal yang diberikan secara keseluruhan perolehan yang di dapat oleh mahasiswa untuk soal nomor 1-3 berturut-turut berkisar 100\%, 99\% dan 99\%. Untuk soal nomor 4 dan 5 tentang kitab faroid perolehan berturut-turut $11,53 \%$ dan $16,07 \%$. Dari hasil perolehan hasil analisis ternyata persentase yang terendah ada pada soal perhitungan yang dalam hal ini ada hubunganya dengan pembelajaran matematika pada materi pecahan, ini berarti pemahaman mahasiswa dalam merinci bagian bagian dari kitab faroid belum tuntas ( belum sesuai denganyang diharapkan). Untuk perkulihan berikutnya perlu kiranya dosen yang mengajar mata kuliah figih dapat kiranya mengalokasikan waktu yang maksimal sehingga bisa lebih banyak waktu memberikan contoh-contoh soal yang bervariasi agar mahas iswa dapat ga mbaran dalam mengerjakan soalsoal yang diberikan. sehinggaa mereka bisa mengaplikasikan meteri tentang kitab faroid ini sesuai dengan sariat islam baik dalam keluarganya masing-masing maupun dalam kehidupan bermasyarakat.

\section{DAFTAR PUSTAKA}

Abdurrahman Ad-Dimasyqi, S.-'. B. (2014). Fiqh Empat Mahzab Terj."Abdullah Zaki Alkaf. Bandung: Hasyimi.

Abdurrahman, M. (2003). Pendidikan Bagi Anak Berkesulitan Belajar. Jakarta: PT, Rineka Cipta. Dalais, M. (2007). Kiat Mengajar Matematika di Sekolah Dasar. Padang: UNP Press .

Gagne. (1977). The Condition of Learning. United State of America.

Kurnia, A. (2015, April 11). Retrieved from http://manajemen-penulisan-teknik-analisisdata.html

Nasution, A. H. (2012). Hukum Kewarisan. Jakarta: PT. Raja Grafindo Persada.

Sabiq, S. (1996). Fikih Sunnah. Bandung: PT. Al-Ma'arif.

Sudijono, A. (2013). Pengantar Evaluasi Pendidikan. Jakarta: PT Raja Grafindo.

Sugiyono. (2013). Penulisan Pendidikan Pendekatan Kuantitatif, Kualitatif, dan $R \& D$. Bandung: Alfabeta.

Syafrilia, N. (2015, maret 27). Definisi dan Pengertian Analisis Menurut Para Ahli. Retrieved from http://academia.edu.htm

Syah, M. (2011). Psikologi Belajar. Jakarta: PT Raja Grafindo. 